\title{
GCU
}

Glasgow Caledonian

University

University for the Common Good

\section{Wrestling with wicked problems? The value of business plan competitions to social entrepreneurship education}

Teasdale, Simon; Steiner, Artur; Roy, Michael James

Published in:

Journal of Nonprofit Education and Leadership

DOI:

10.18666/JNEL-2020-V10-I3-9612

Publication date:

2020

Document Version

Author accepted manuscript

Link to publication in ResearchOnline

Citation for published version (Harvard):

Teasdale, S, Steiner, A \& Roy, MJ 2020, 'Wrestling with wicked problems? The value of business plan

competitions to social entrepreneurship education', Journal of Nonprofit Education and Leadership, vol. 10, no. 3. https://doi.org/10.18666/JNEL-2020-V10-I3-9612

\section{General rights}

Copyright and moral rights for the publications made accessible in the public portal are retained by the authors and/or other copyright owners and it is a condition of accessing publications that users recognise and abide by the legal requirements associated with these rights.

Take down policy

If you believe that this document breaches copyright please view our takedown policy at https://edshare.gcu.ac.uk/id/eprint/5179 for details of how to contact us. 
Wrestling with wicked problems? The value of business plan competitions to social entrepreneurship education

\author{
Simon Teasdale, Artur Steiner and Michael J. Roy \\ Yunus Centre for Social Business and Health, \\ Glasgow Caledonian University, \\ George Moore Building, Cowcaddens Road, \\ Glasgow, G4 0BA \\ contact: $\underline{\text { simon.teasdale@gcu.ac.uk }}$
}

Authors' pre-publication version

Cite as:

Teasdale, S., Steiner, A. and Roy, M.J. (2020) 'Wrestling with wicked problems? The value of business plan competitions to social entrepreneurship education' Journal of Non-profit

Education and Leadership 10(2) 


\begin{abstract}
In this work we present an account of our experiences with a group of graduate students studying social entrepreneurship at Master's level. They participated in a prominent international business plan competition which challenges students to come up with a solution to a significant real world problem. We facilitated the process of their involvement with the support of a visiting colleague to identify what the students thought was a workable solution. Our students learned about the nature, scale and complexity of so-called 'wicked problems' and potential solutions. We consider that practice-based co-curricular activities are not an easy option for faculty: that students need extensive support, and while they can gain significant learning from such experiences, we consider that learning outcomes are best enhanced through students working closely with those with a deep, contextualised familiarity of context in order to co-produce integrated solutions.
\end{abstract}




\section{Introduction}

Over the last twenty years increasing attention has been paid to the concept of social entrepreneurship, broadly understood as the innovative use of resources aimed at catalysing social change / addressing social needs (Mair \& Martí, 2006). This attention has not been wholly welcomed by non-profit scholars. While some recognise the potential for non-profits to develop new revenue streams, or generate employment for their clients (Cooney, 2011), others see social entrepreneurship, and the associated organisational form of social enterprise, as representing the encroachment of business-like approaches into the non-profit sector (Dart, 2004). This has been problematized as downplaying the complexity of social problems in the pursuit of (over) simplified market-based solutions (see, for example, Dey \& Steyaert, 2014; Eikenberry, 2009).

On the surface, non-profit studies and social entrepreneurship scholarship share many similarities, most notably an explicit focus on social justice and social change (Mirabella \& Eikenberry, 2017). Teaching of both non-profit management and social entrepreneurship place considerable emphasis on experiential learning (Austin \& Rangan, 2018; Tavanti \& Wilp, 2018). Occasionally they share the same syllabi (Mirabella \& Eikenberry, 2017). However, despite these similarities there is relatively little dialogue between the two approaches. Indeed, there might be considerable resistance to the incorporation of social entrepreneurship into nonprofit education and research more widely. Some commentators argue that the 'top-down' approach to social change associated with social entrepreneurship poses a threat to the cornerstones of civil society: democracy, social justice and inclusion (Eikenberry, 2009; R. M. Mirabella \& Eikenberry, 2017).

While we hold some sympathy with this view, we would also suggest that it is important not to 'throw the baby out with the bathwater'. Whether we like it or not, social enterprise is an increasingly important element of the non-profit sector. Funders demand innovative new 
projects. In the United Kingdom (UK), the site of our teaching, grants are readily (and somewhat perversely) available to non-profits seeking to transform themselves into social enterprises free from grant dependency (Dey \& Teasdale, 2016). And students are born into a world where business is the accepted way of doing things. Television programmes such as 'The Apprentice' and 'Dragon's Den' highlight the ingrained legitimacy of entrepreneurship and the seeming importance of being able to make a five-minute pitch to potential funders.

This essay was initially planned as a polemic against 'responsible management education' and thus retains a number of polemical qualities. We present an account of how the three authors, in teaching a course aimed at critically evaluating social entrepreneurship and its place in the non-profit sector, were confronted with a group of students who demanded more co-curricular contact time and, more significantly, were keen to learn more about the practice of actually doing social entrepreneurship. This led us, somewhat reluctantly, and - admittedly - somewhat cynically, to enter the world of social entrepreneurship 'business plan competitions', and eventually to reflexively question our own preconceptions about the dichotomy between non-profit and social entrepreneurship approaches to social change. Here we reflect upon our experiences of teaching social entrepreneurship, and particularly the knowledge gained from our students' experience of participating in an international business plan competition, and suggest that there may be a role for similar approaches to experiential learning within non-profit education.

Our essay proceeds as follows. First we provide some context to our case with a brief account of how we found ourselves teaching social entrepreneurship, and a more formal review of social entrepreneurship education, with particular emphasis on the role of business plan competitions. Next we describe the case, focusing on how our students worked to develop a business plan to address the lack of pre-school education in urban centres in the world's poorest countries. Finally, we describe the impact on our students and draw out lessons for those 
seeking to use such business plan competitions to aid experiential learning. In essence, we consider that students can learn a great deal about the complexity of social problems, and the appropriateness of business solutions, through attempting to design such solutions.

\section{From 'donuts for social change' to teaching social entrepreneurship by accident}

Whether by accident or design, in recent years our institution has become increasingly involved in the world of social entrepreneurship education. This was, first of all, a result of the introduction (and design) of a new Master's programme and, subsequently, a number of faculty members becoming involved in and gaining responsibility for inculcating a culture of socially innovative practice and thinking across our institution through the process of gaining 'AshokaU Changemaker Campus' accreditation (AshokaU, 2017). Coming predominantly from backgrounds in sociology and public policy and administration, we have - individually and as writing teams - a moderately significant body of papers critiquing social entrepreneurship as the extension of neoliberal thought into the non-profit sector. Two of the three authors are nominally situated within the Business School. Here, many of our institutional colleagues have thrown themselves wholeheartedly behind the Principles of Responsible Management Education (PRME) agenda. Others have been dragged more reluctantly into the world of responsible management education. Those responsible for teaching every course in our Department of Business Management have been forced to explain how the content aligned with, and delivered, the PRME agenda as part of a formal course validation process. Our inboxes are continually cluttered with examples of how socially responsible businesses, such as Unilever, are delivering a more sustainable future to our children. Student societies have been encouraged to help demonstrate how the transformative power of business could change the world for the better. On one memorable occasion one of us was accosted to buy donuts 
during a walk across campus by a group of students proudly wearing their ENACTUS ${ }^{1}$ T-shirts, with the profits of the sale helping to fund a student trip to London to participate in a competition. Not long before, a paper had been published on 'gastro-philanthropy' (Nickel \& Eikenberry, 2013) which had critically examined the reduction of philanthropy to the impulsive purchase of a sugary treat, and questioned the 'transformative effects' on purchasers and supposed beneficiaries. Considering the moral dubiousness of encouraging the consumption of donuts for the 'common good' in a city noted for obesity and health inequalities (Roy, Donaldson, Baker, \& Kay, 2013) made us reflect upon whether the ends justified the means.

With regards to the donuts, this question is, at least on the surface, relatively simple to answer: if the students involved had studied social policy rather than business management we might expect that their approach to social change would have been rather different. However, there are more complex situations in which students and social entrepreneurs find themselves, where moral and ethical dilemmas may need to be overcome for the 'common good'. Generally speaking, our teaching philosophy has been shaped by our own exposure to (critical) academic disciplines and life experience. In teaching our course, Global Social Entrepreneurship, we considered that students should be exposed to social entrepreneurship within its wider political context and be left to decide themselves whether and how to engage with the phenomenon. In essence, this involved teaching about social entrepreneurship rather than how to do social entrepreneurship. To some extent this perspective has been influenced by our observations of students spending more time selling donuts, cupcakes and chocolates (or some other products or services) than they did learning about the structural inequalities which their actions really ought to seek to address (rather than, on occasion, exacerbate). We were keen for our students to step back off the social entrepreneurship education treadmill of learning by doing, and

\footnotetext{
1 "We believe investing in students who take entrepreneurial action for others creates a better world for us all." http://enactus.org/
} 
instead begin to question what and why they were supposed to be doing. Just to clarify, we were not opposed to experiential learning per se, but felt there was a reasonable argument that the encroachment of business school approaches into the realm of social change had gone too far, and we wished to turn the clock back.

To some extent, however, our perspective was challenged by a cohort of students who demanded more co-curricular contact time and, more significantly, were keen to learn more about the practice of actually doing social entrepreneurship. Before describing this case, we first review recent developments in the field of social entrepreneurship education, which show that our own preconceptions were not entirely invalid.

\section{A note on social entrepreneurship education}

Since Tracey \& Phillips (2007) highlighted a lack of discussion in relation to the special challenges faced in educating social entrepreneurs - managing accountability, managing a double bottom line, and managing identity - social entrepreneurship education has developed rapidly (Wiley \& Berry, 2015) and most business schools would now appear to offer some form of social entrepreneurship education (Mirabella \& Eikenberry, 2017). The growing number of social entrepreneurship courses has been accompanied by a decline in non-profit courses, meaning a significant decline in teaching content related to social and community development (Andersson, 2011; Mirabella \& Young, 2012).

Importantly, teaching social entrepreneurship has extended beyond business schools and into diverse faculties such as public administration, occupational therapy, public policy, law, and design. A 2012 special issue of Academy of Management Learning \& Education devoted to social entrepreneurship education suggested that the challenges referred to by Tracey and Phillips were now at least being discussed. This special issue broke new ground by emphasising that social entrepreneurs face unique challenges, going beyond the traditional view observable in many social entrepreneurship programs that undertaking and managing a 
social venture is more or less the same as with any other type of organisation. Moreover, there was an explicit recognition that social entrepreneurs need more than just the business planning skills that business schools were best placed to teach. Early social entrepreneurship programmes, it could reasonably be argued, simply added 'a thin coat of 'social' (Worsham, 2012) onto existing entrepreneurship and business modules. Until recently, however, there has been little research evidence to inform us about the landscape of social entrepreneurship education.

There are well worn arguments that social entrepreneurship education requires a special approach due to a distinctive set of competencies needed by social entrepreneurs and complexities associated with the (often competing) social and financial logics within social enterprises (Tracey \& Phillips, 2007). Social entrepreneurs need to balance investments in the revenue generating aspects of the business and finances spent on achieving social objectives (Steiner \& Teasdale, 2016). Social and commercial goals are rarely in alignment (Teasdale, 2012) and the need to balance the competing logics of social entrepreneurship can often be glossed over in educational settings, with "the social [becoming] too weak, and the entrepreneurship [...] too managerialized" (Hjorth, 2013, p. 35). Another challenge for social entrepreneurship education is that it is too often informed by inspiring case studies of charismatic 'heroic' social entrepreneurs (Dey \& Steyaert, 2012), capable of creating social change with barely any resources (Di Domenico, Haugh, \& Tracey, 2010). Academics and educators frequently present a very simplistic view of a social entrepreneurship phenomenon that, in practice, is complex and challenging. Less attention is given to failure of socially entrepreneurial ventures (Mirabella \& Eikenberry, 2017) and there are good arguments that 'failure stories' should be studied more closely so the future generation of social entrepreneurs is aware of at least some of the pitfalls and challenges (viz. Scott \& Teasdale, 2012; Tracey \& Jarvis, 2006). 
If the objective of social entrepreneurship is to achieve positive social change, then it would seem to make sense for universities to focus on empowering students to achieve this through a variety of approaches including exposure to subjects that are perhaps not 'mainstream' within many business schools, but which are more familiar in other social sciences, and which involve debates on social justice, ethics and reasoning, building and maintaining democracy, or on building and maintaining social capital and connectedness (Williamson, Burke, \& Beinecke, 2011). However, when researching social entrepreneurship education programmes in the US, Mirabella \& Eikenberry (2017) observed that programmes more commonly relate to performative and managerialist values, but frequently omit crucial social or political aspects of developing and running social ventures. They found very few courses exploring social entrepreneurship through the lens of political economy. While public administration has recognised and asserted the distinctions between the public, private, and non-profit sectors, social entrepreneurship serves to 'blur the boundaries' between sectors, and thus disciplines (Arsneault \& Vaughan, 2015). The knowledge and skills necessary to operate across sectors - or effectively negotiate the 'intersectionality' (Robichau, Fernandez, \& Kraeger, 2015) involved in (successful) social entrepreneurship - has been the focus of recent work. While activities such as developing business plans are still seen as an 'uncommon topic' for the teaching of social entrepreneurship from the perspective of public administration (Arsneault \& Vaughan, 2015), experiential learning approaches have been found to enhance students' knowledge of the socio-political structure in which social entrepreneurs operate. Van Gelder \& Dougherty (2012, p. 370), for example, found substantial differences between students who had prior public administration experience compared to those without, "especially in terms of understanding context and the political dimension of public administration". 
What is also largely missing are experimentations, practical skills and analytical frameworks (Kickul, Terjesen, Bacq, \& Griffiths, 2012). From an interview with Greg Dees, who is frequently perceived as one of the 'founding fathers' of social entrepreneurship education, Worsham (2012) explains the need for a balanced programme, blending theory and practice, employing different teaching methods where students can obtain a full set of relevant skills to succeed as potential social entrepreneurs. He suggests that learning outcomes should come from more authentic, engaging experiences around the problem, with opportunities for course participants to listen and observe as well as receive feedback. Some of the most useful teaching techniques that have been identified involve: engagement with interdisciplinary research teams to target a particular social issue; fieldwork with client organisations, whether in local communities, or international examples; placements and internships in social ventures in unfamiliar context (e.g. in developing countries); and/or 'shadowing' social entrepreneurs to learn about their day-to-day challenges and the way to deal with them, including guest speakers who can talk about 'what works' and, just as importantly, 'what doesn't work' in practice (Elmes, Jiusto, Whiteman, Hersh, \& Guthey, 2012; Tracey \& Phillips, 2007; Weber, 2012). This need for authentic, engaging experiences implies that an appreciation of the context in which social entrepreneurship activities takes place (De Bruin \& Lewis, 2015; Newth \& Woods, 2014), including the lived experiences of often marginalized or stigmatized groups of people (Lysaght et al., 2018). Elmes et al. (2012) indicate, however, that many of the social entrepreneurship courses in the US and UK refer to 'context' through a conventional notion of environment sourced from organisational theory and business studies, with narrow and simplified assumptions about the social context in which social entrepreneurship takes place. The socio-political context - shaped by neoliberal policies, public spending cuts, rapid dismantling and reconfiguring of welfare states, and new emphases on community empowerment and co-production - all have implications for the types of social vulnerabilities 
that social entrepreneurship often seeks to address (Montesano Montessori, 2016) and thus how social entrepreneurship operates in practice. As Lewis (2013, p. 813) explains: "The webs of interactions that inspire and inform socially entrepreneurial acts occur within a specific context, whether local, global or somewhere in-between." Of course, the concept of 'situated learning' where learning is "an integral and inseparable aspect of social practice" (Lave \& Wenger, 1991, p. 31) is well known. But translating theory and academic work on social entrepreneurship into an effective classroom experience, where an understanding of systems, policies and economic frameworks, complex patterns of relationships, political dynamics and local histories, the need to build a diverse network of allies, and the 'performative' skills necessary to secure legitimacy in the eyes of stakeholders (Dey \& Teasdale, 2016; Steiner \& Teasdale, 2016) are skills that are rarely taught (Weber, 2012).

The same cannot be said, however, of business plans as a teaching tool, particularly when social entrepreneurship is taught within the context of businesses and management studies. This is despite Honig \& Karlsson (2004, p. 29) finding that "the value and positive effects of business plans have been taken for granted rather than critically studied." Since that paper was published fifteen years ago, to our knowledge no research exploring the outcomes and long-term effect of business plans on the activities of nascent social entrepreneurs has been conducted. The usefulness of the tool for social entrepreneurship education and practice can, therefore, be critically questioned. That has not stopped a plethora of social business plan competitions from springing up, however, and it is our experiences of our students participating in such a competition to which we next turn our attention.

\section{Competition time}

The student group in question were from very diverse backgrounds (see Table 1). Ella, our North American student, approached one of us at the end of class and explained that while she was enjoying the programme, she would prefer more contact time with the Professors, and 
more time devoted to the 'doing' of social entrepreneurship as opposed to the theory. By chance earlier that day we had received an email notifying us about the Hult Prize: a competition which challenges teams of students to develop a socially entrepreneurial solution to some of the major challenges facing the world, and was offering a $\$ 1$ million prize for the winning proposal. The Hult Prize Foundation has been termed the 'Nobel Prize for Students' and has been featured in a TIME Magazine Cover Story highlighting the 'Top 5 Ideas Changing the World.' ${ }^{2}$ The challenge posed that year (2015) was to address the lack of pre-school education in urban centres in the world's poorest countries. Student teams had to submit a one-page outline of a business solution addressing the problem. Of the 20,000 applications less than $5 \%$ would be selected to participate in the regional finals which involved 'pitching' their business plan to judges.

Table 1

Demographics of Competition Team

\begin{tabular}{lllll}
\hline Student & $\begin{array}{l}\text { Country of } \\
\text { origin }\end{array}$ & Age & Sex & $\begin{array}{l}\text { Enrolment } \\
\text { Status }\end{array}$ \\
\hline Uchechi & Nigeria & $25-39$ & Male & $\begin{array}{l}\text { Full time } \\
\text { Masters } \\
\text { student }\end{array}$ \\
Ella & Canada & $20-24$ & Female & $\begin{array}{l}\text { Full time } \\
\text { Masters } \\
\text { student }\end{array}$ \\
& & & & Full time \\
Ariela & Italy & $20-24$ & Female & $\begin{array}{l}\text { Masters } \\
\text { student }\end{array}$ \\
& & & & Full time \\
Pascal & Portugal & $30-34$ & Male & Masters \\
& & & & student \\
& & & Full time \\
Asha & Kenya & $20-24$ & Female & Masters \\
& & & & student \\
\hline
\end{tabular}

${ }^{2}$ http://www.hultprize.org/ 
Not all of the students were as keen to devote extra time to their studies, but we assembled a group of five students and scheduled weekly meetings with the programme leader. Outside of this time the students worked collaboratively to develop their business idea. The students decided to focus on Bangladesh before rolling their plan out to the rest of the world; they had recently been visited by our (then) University Chancellor, the Nobel Peace Prize winner and founder of the Grameen Bank (and probably the world's most famous social entrepreneur), Muhammad Yunus. One of the students (Asha) had placed their child at our University-funded nursery and was keen to develop similar standards of pre-school education in Bangladesh. Another student (Uchechi) found a slightly dubious report suggesting that every dollar invested in pre-school education leveraged $\$ 40$ worth of value in the future. The solution, to their eyes, was straightforward: they would borrow the initial capital investment and use their $\$ 1$ million prize to generate future cash savings. They imagined that the Bangladeshi government would be keen to invest once they realised the potential cost savings and potentially future benefits. Somewhat fortuitously, we were then joined by a Bangladeshi academic visiting our university through a British Council/Commonwealth Visiting Fellowship. He was able to put the students in touch with senior people at BRAC ${ }^{3}$ and Grameen in Dhaka to help give an idea of some of the practical challenges they might find on the ground. Our university also has an ongoing partnership with Grameen to run the Grameen Caledonian College of Nursing, training the daughters of Grameen borrowers to western standards of nursing. The students decided to adapt this model to develop a partnership between Grameen and Glasgow Caledonian University to set up a university programme in Bangladesh to train pre-school (kindergarten) education professionals. The students, who were also being taught about microfinance, decided a useful addition to the proposal would be the provision of

\footnotetext{
${ }^{3}$ http://www.brac.net/
} 
microfinance opportunities to enable potential students on the kindergarten training programme to pay their course fees. The idea being that the investment in pre-school education would lead to better job opportunities and the ability to repay loans for course fees.

To this point, the plan could (at least in theory) be funded through the $\$ 1$ million prize. However, the students had overlooked the small matter of where the pre-school education would take place. After speaking to people in Bangladesh they discovered that facilities for pre-school education already existed. They also found that many large workplaces, particularly in the garment industry, would be prepared to offer facilities for pre-school education on-site.

It was during this process, though, that the students discovered that a lack of pre-school provision was not necessarily the main problem: they came across another report highlighting that drop-out rates among pre-school and primary school aged children was very high compared to countries in the global north. Conversations with professionals in Bangladesh, facilitated by our Bangladeshi academic, suggested that this was due to a combination of factors including: low-quality provision; parents moving jobs; or from jobs into self-employment; and (a major problem) children being forced to enter the workplace and contribute economically to poor households. The students conducted a review of academic literature and decided that the existing evidence suggested that the best way to combat this problem was to reward the parents if their children completed at least a semester of pre-school education.

Two of the students then set out to cost their plans. Perhaps displaying some of the signs of youthful optimism that have long since left us, they proudly announced that their plans would generate at least $\$ 10$ billion of future value (based on projected costs of $\$ 2.5$ billion). Our Bangladeshi academic explained that it was highly unlikely the Bangladeshi government would be persuaded to invest $\$ 2.5$ billion pounds in such a scheme (less, of course, the $\$ 1$ million prize from Hult). Not to be deterred, the students then brought in another aspect of their 


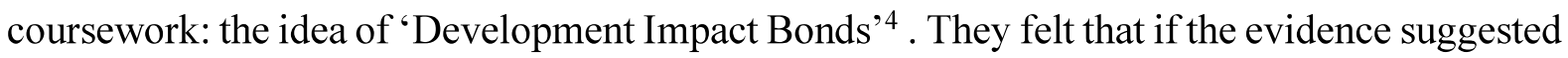
the future return was attractively high, then institutional investors could be persuaded to invest now to generate future returns. However, they came up against problems familiar to most public policy academics, in that the returns generated through social investment do not always fall upon those making the investment. While never fully resolved, the students decided that multinational companies would be keen to invest in the scheme, as would NGOs such as OXFAM and local organisations such as BRAC. In essence, the idea was akin to traditional corporate philanthropy, in that multinationals and NGOs would 'front load' the investment in pre-school education facilities and paying for children to attend, while returns would be seen in terms of future increased prosperity (and thus GDP) of Bangladesh.

Perhaps fortuitously, at this preliminary stage in the competition the students did not have to submit their cost workings or estimates. However, after their outline was submitted, they were selected as one the top 5\% of proposals and invited to attend the European regional finals in London. With the benefit of hindsight and a healthy dose of cynicism we might suggest that the proposal was selected to go forward as it combined a holy trinity of 'sexy topics' in social entrepreneurship: cross-sectoral collaboration, microfinance and Development Impact Bonds (see Appendix One).

\section{Ill-fitting suits, mobile apps and a visit to London}

Over the next three months each of the students spent around eight hours a week developing their 'pitch' for the regional finals, supported by a faculty member who met weekly with the students and commented critically on their evolving business plan. They were able to draw on skills developed through more traditional business school modules offered as part of their degree programme, for example in business-planning and strategy. Additionally, they were pushed by the facilitator to investigate a wider research literature (predominately social

\footnotetext{
${ }^{4}$ https://www.cgdev.org/initiative/development-impact-bonds-0
} 
policy and development studies-based) around the impact of pre-school education, its cost, and successful (and unsuccessful) ways of delivery. As part of the module 'Global Social Entrepreneurship' all the students had been exposed to wider developments in the area of social entrepreneurship and were keen to incorporate aspects of social impact bonds and microfinance into their final pitch.

The students travelled to London and stayed the night in a hotel near the venue for the competition. We ran through a final rehearsal of their 'pitch' late on the eve of the competition, which had improved dramatically since an earlier - somewhat disastrous - practice run in front of the Dean of the School. A design company based in Bangladesh had helped them produce professional slides, possibly motivated in part by a desire to avoid any further Skype conversations about setting up a nursery on their premises. While many of the nerves they had earlier displayed had dissipated, they returned with a vengeance on the day of the competition. The students were attired in a selection of ill-fitting (borrowed) suits, professional business attire (our North American scholarship student) and a cocktail dress. The team from Oxford University were drawn immediately before our team in the heat; the polished nature of their performance (and matching suits) probably added to our students' nervousness.

We watched through the window of the room as our team went before the panel. During the questions at the end we noticed that one of the judges looked particularly perplexed. In the debrief afterwards our team captain reflected on the questions they had fielded concerning the costs of implementing their idea. They had responded promptly and confidently their carefully researched answer of $\$ 2.4$ billion (they had managed to shave $\$ 100$ million from their original estimate). The questioner, somewhat confused, had returned with the quite reasonable question: 'why would anyone want to invest that much money in five students?' Undeterred, the team captain, seemingly perplexed by the stupidity of the question, responded 'because we are from the University for the Common Good!' Later that day we found out, unsurprisingly, that our 
team had not won: Oxford had won the heat, with their idea of a mobile app. The students were understandably disappointed, but somewhat less understandably, completely undaunted, immediately setting about making plans to raise the start-up capital in other ways. (Indeed, one of the students later emailed the Principal of the University, who gave her time to the students and seemed to seriously consider the idea). By the time we had got to the prize winners dinner we were exhausted, and observed our team kindly and confidently explaining to the students from Oxford why the judges had been wrong in their assessment, and why a mobile app was never going to work in practice.

\section{The end of cynicism: lessons for social entrepreneurship education}

In the introductory section of this paper we (perhaps unfairly) characterised business school approaches to social entrepreneurship education as being all about quick and easy solutions, business plans and 'dragons den'-style competitions, while social policy and public administration approaches tend to focus on the need to understand the complexity of social problems and the challenges of finding workable solutions. Our literature review helped to adjust some of our preconceptions, but also see that this characterisation was not wholly without merit.

In line with the premise of business plan competitions our students gained an immeasurable amount of experience, including confidence from competing against far more prestigious universities in the final. While the precise impact on their pedagogical development probably cannot be fully captured by any formal evaluation of the experience, all of the students achieved significantly higher grades in the semester after the competition than the preceding one, and all achieved excellent scores for their final Master's dissertations. This led us to rethink our attitude to the value of such business plan competitions and we subsequently drew upon our experiences to design an accredited module focused on investigating solutions to real life social problems. 
Our own experiences talking to the students, and observing them over the course of not only the competition period itself, but the longer duration of their studies, suggest that the primary value of the process was that students learned a great deal about the complexity of preschool education in a country such as Bangladesh, how it intersects with other social problems, and the huge cost of remedying this so-called 'wicked problem', and yet were not completely overwhelmed or defeated by the scale of the problem or the solution they came up with. Our key learning point here would be that through attempting to design solutions to complex social challenges, students (and faculty) can learn a great deal about large-scale problems, how they interrelate to structural factors in the socio-political environment, and the importance of contextualised, place-based solutions.

Secondly, the opportunities provided to the students were facilitated through being able to work directly with somebody with practical experience of trying to 'get things done' in the complex (and often chaotic, to our eyes) Bangladeshi context, in addition to the academic support. This provided the students with access to others working in the area with direct knowledge of local context, and so they were able to quickly establish what might or might not work, what has been tried before, and potential pitfalls. Here the key learning point would be that students need to work closely with those who understand the problem and/or context in order to develop meaningful solutions that recognise the complexity of, and contextualise, the problem.

Finally, and relatedly, at the beginning of the process our attitude was that 'at least it won't take up too much staff time'. The time contributed by academic staff and our Bangladeshi colleague was considerable, probably more than would be devoted to a traditional module in terms of teaching, seminar and marking time. From a facilitator's perspective this time was highly enjoyable, as it gave us the opportunity to apply our skills in different ways. But 
nonetheless, a practical module of the type we have developed subsequently should not be seen as an 'easy option' for faculty: students need extensive support to benefit from the experience.

On a final note then, our experiences led us to change our perspective. We suggest that many university courses may well be enhanced by involvement in social entrepreneurship business plan competitions. Relatedly, business schools may also gain from their students working closely with 'real people' in community groups in order to understand the complexity involved in wrestling with wicked problems. The main point to note is that students may not have devised a solution to the lack of pre-school education in Bangladesh, but they learned a significant amount about the nature of social problems through trying to develop a solution. The value of their experience is perhaps best articulated in the words of one of the students:

"We had to understand the solution in the context of the way the world works...not just in the UK or North America, but also the slums of Bangladesh. We had to understand how to work with each other given we came from very different backgrounds. We had a scholar from Dhaka, Bangladesh ... we used him as an advisor to our project. He gave us contacts in earlyyears education in Bangladesh... there's nothing as valuable as learning from people with first-hand experience... It was the best experience I had at GCU with respect of applying the knowledge and theory I had been learning in the context of a real world problem. It was the best opportunity for us to recognise the complexity of social problems and that there are no easy solutions." (Video testimony from Ella, available on request from the lead author). 


\section{Appendix One: Outline Submission to Hult prize}

The Glasgow Caledonian University Hult Prize Team should be selected to move forward in competition based upon our innovative solution to the issue at hand, which involves the following three components designed to complement, strengthen and extend existing infrastructure:

\section{Building upon the Grameen Caledonian College of Nursing partnership}

The Grameen Trust and Glasgow Caledonian University (GCU) partnered in 2010 to create the Grameen Caledonian College of Nursing (GCCN) in Dhaka, Bangladesh. The first social business of its kind, GCCN has seen significant success in addressing a lack of qualified nursing and midwifery practitioners in Bangladesh.

Building upon this model, GCU will extend provision to utilize the skill systems and infrastructure already in place. Professionals in early childhood education (ECE) from GCU will spearhead a newly designed program to train local ECE practitioners and equip them with a leading curriculum designed for children, aged 0-6, in developing nations.

GCCN will equip the first cohort of practitioners with the skills required to train future staff, permitting $100 \%$ local delivery in the future. Nonetheless, Bangladesh witnesses a high preprimary school drop-out rate, and well-trained practitioners may not completely address this related issue.

\section{Utilizing Development Impact Bonds}

In order to discourage pre-primary school dropout, our solution involves creating and implementing a Development Impact Bond (DIB). DIBs are based upon the Social Impact Bond model and we anticipate that a group of socially-oriented multinationals such as Nike or others involved in the garment industry who have a vested interest in the abolishment of child labor and the improvement of workforce skills in Bangladesh will be compelled to invest. Additional funders could also include not-for-profits including Oxfam and Unicef, given the alignment between this DIB and their mission-driven purpose.

The return on investment of the DIB would be calculated based upon the additional income that children can earn if they attend school. ECE increases children's future earning potential and directly contributes to an increase in national GDP. Therefore, the DIB replaces the income forfeited through forgoing child labor, and in the long-term, creates a more prosperous nation.

\section{Offering microfinance support}

Our solution capitalizes upon an existing partnership with Grameen Bank in order to promote microfinance and business support services to eligible clients not-yet-reached. The Chancellor of GCU is Nobel Peace Laureate Muhammad Yunus. GCU will send students to work alongside Grameen's existing networks to provide expert knowledge regarding the importance of ECE. Parents of children who are interested in Grameen Bank's microcredit services as a way of improving their livelihoods will be offered an opportunity to become involved with the program, as long as they commit to sending their children to school on a long-term basis.

Finally, we would emphasize that this pilot program in Bangladesh can be scaled globally by similar partnerships between universities, students, social businesses, microfinance providers, governments and corporations. Of course, contextual circumstances will need to be taken into consideration, however Bangladesh serves as a suitable location to begin due to the existing infrastructure provided by government, civil society, and multinational businesses. 


\section{References}

Andersson, F. O. (2011). Finding New Ways to Understand and Teach Entrepreneurship in the Nonprofit Sector: Introducing the Nonprofit Entrepreneurship Tree. Journal of Nonprofit Education and Leadership, 1(2), 78-90.

Arsneault, S., \& Vaughan, S. K. (2015). Blurred Lines: Preparing Students to Work Across the Public, Nonprofit, and For-Profit Sectors. Journal of Public Affairs Education, 21(3), 311.

AshokaU. (2017). Changemaker Campus. Retrieved 29 January 2018, from Ashoka U website: http://ashokau.org/changemakercampus/

Austin, J., \& Rangan, V. K. (2018). Reflections on 25 Years of Building Social Enterprise Education. Social Enterprise Journal. https://doi.org/10.1108/SEJ-09-2018-0057

Cooney, K. (2011). An Exploratory Study of Social Purpose Business Models in the United States. Nonprofit and Voluntary Sector Quarterly, 40(1), 185-196.

Dart, R. (2004). The Legitimacy of Social Enterprise. Nonprofit Management and Leadership, 14(4), 411-424.

De Bruin, A., \& Lewis, K. V. (2015). Traversing the Terrain of Context in Social Entrepreneurship. Journal of Social Entrepreneurship, 6(2), 127-136.

Dey, P., \& Steyaert, C. (2012). Social Entrepreneurship: Critique and the Radical Enactment of the Social. Social Enterprise Journal, 8(2), 90-107.

Dey, P., \& Steyaert, C. (2014). Rethinking the Space of Ethics in Social Entrepreneurship: Power, Subjectivity, and Practices of Freedom. Journal of Business Ethics, 133(4), $627-641$.

Dey, P., \& Teasdale, S. (2016). The Tactical Mimicry of Social Enterprise Strategies: Acting 'As If' in the Everyday Life of Third Sector Organizations. Organization, 23(4), 485504. 
Di Domenico, M., Haugh, H., \& Tracey, P. (2010). Social Bricolage: Theorizing Social Value Creation in Social Enterprises. Entrepreneurship Theory and Practice, 34(4), $681-703$.

Eikenberry, A. M. (2009). Refusing the Market: A Democratic Discourse for Voluntary and Nonprofit Organizations. Nonprofit and Voluntary Sector Quarterly, 38(4), 582-596.

Elmes, M. B., Jiusto, S., Whiteman, G., Hersh, R., \& Guthey, G. T. (2012). Teaching Social Entrepreneurship and Innovation From the Perspective of Place and Place Making. Academy of Management Learning \& Education, 11(4), 533-554.

Hjorth, D. (2013). Public Entrepreneurship: Desiring Social Change, Creating Sociality. Entrepreneurship \& Regional Development, 25(1-2), 34-51.

Honig, B., \& Karlsson, T. (2004). Institutional Forces and the Written Business Plan. Journal of Management, 30(1), 29-48.

Kickul, J., Terjesen, S., Bacq, S., \& Griffiths, M. (2012). Social Business Education: An Interview With Nobel Laureate Muhammad Yunus. Academy of Management Learning \& Education, 11(3), 453-462.

Lave, J., \& Wenger, E. (1991). Situated Learning: Legitimate Peripheral Participation. Cambridge: Cambridge University Press.

Lewis, K. V. (2013). The Power of Interaction Rituals: The Student Volunteer Army and the Christchurch Earthquakes. International Small Business Journal, 31(7), 811-831.

Lysaght, R., Roy, M. J., Rendall, J. S., Krupa, T., Ball, L., \& Davis, J. (2018). Unpacking the Foundational Dimensions of Work Integration Social Enterprise: The Development of an Assessment Tool. Social Enterprise Journal, 14(1), 60-70.

Mair, J., \& Martí, I. (2006). Social Entrepreneurship Research: A Source of Explanation, Prediction, and Delight. Journal of World Business, 41(1), 36-44. 
Mirabella, R. M., \& Eikenberry, A. M. (2017). The Missing "Social” in Social Enterprise Education in the United States. Journal of Public Affairs Education, 23(2), 729-748. Mirabella, R., \& Young, D. R. (2012). The Development of Education for Social Entrepreneurship and Nonprofit Management: Diverging or Converging Paths? Nonprofit Management and Leadership, 23(1), 43-57.

Montesano Montessori, N. (2016). A Theoretical and Methodological Approach to Social Entrepreneurship as World-Making and Emancipation: Social Change as a Projection in Space and Time. Entrepreneurship \& Regional Development, 28(7-8), 536-562.

Newth, J., \& Woods, C. (2014). Resistance to Social Entrepreneurship: How Context Shapes Innovation. Journal of Social Entrepreneurship, 5(2), 192-213.

Nickel, P. M., \& Eikenberry, A. M. (2013). Gastrophilanthropy: Utopian Aspiration and Aspirational Consumption as Political Retreat. Reconstruction: Studies in Contemporary Culture, 12(4).

Robichau, R. W., Fernandez, K., \& Kraeger, P. (2015). An Integrated Framework of InterSectorality: Nonprofitness and Its Influence on Society and Public Administration Programs. Journal of Public Affairs Education, 315-336.

Roy, M. J., Donaldson, C., Baker, R., \& Kay, A. (2013). Social Enterprise: New Pathways to Health and Well-being? Journal of Public Health Policy, 34(1), 55-68.

Scott, D., \& Teasdale, S. (2012). Whose Failure? Learning from the Financial Collapse of a Social Enterprise in 'Steeltown’. Voluntary Sector Review, 3(2), 139-156.

Steiner, A., \& Teasdale, S. (2016). The Playground of the Rich? Growing Social Business in the 21st Century. Social Enterprise Journal, 12(2), 201-216.

Tavanti, M., \& Wilp, E. A. (2018). Experiential by Design: Integrating Experiential Learning Strategies Into Nonprofit Management Education. Journal of Nonprofit Education and Leadership, 8(4), 375-402. 
Teasdale, S. (2012). Negotiating Tensions: How Do Social Enterprises in the Homelessness Field Balance Social and Commercial Considerations? Housing Studies, 27(4), 514 532.

Tracey, P., \& Phillips, N. (2007). The Distinctive Challenge of Educating Social Entrepreneurs: A Postscript and Rejoinder to the Special Issue on Entrepreneurship Education. Academy of Management Learning \& Education, 6(2), 264-271.

Tracey, Paul, \& Jarvis, O. (2006). An Enterprising Failure: Why a Promising Social Franchise Collapsed. Stanford Social Innovation Review, 5(Spring), 55-70.

Van Gelder, M., \& Dougherty, G. W. (2012). Do Students with Experience Know That Much More? Assessing in-Service and Pre-Service Differences in Public Administration Students. Journal of Public Affairs Education, 349-374.

Weber, J. M. (2012). Social Innovation and Social Enterprise in the Classroom: Frances Westley on Bringing Clarity and Rigor to Program Design. Academy of Management Learning \& Education, 11(3), 409-418.

Wiley, K. K., \& Berry, F. S. (2015). Teaching Social Entrepreneurship in Public Affairs Programs: A Review of Social Entrepreneurship Courses in the Top 30 Us Public Administration and Affairs Programs. Journal of Public Affairs Education, 21(3), $381-400$.

Williamson, A. L., Burke, B. F., \& Beinecke, R. H. (2011). Public Service and Social Responsibility: A Role for Public Affairs in Undergraduate Business Education. Journal of Public Affairs Education, 17(3), 367-384.

Worsham, E. L. (2012). Reflections and Insights on Teaching Social Entrepreneurship: An Interview with Greg Dees. Academy of Management Learning \& Education, 11(3), $442-452$. 